\title{
Cerdas Dan Bijak Menggunakan Media Sosial Di Era Digital Literasi Dan Informasi Kepada Siswa Kelas IX SMP N 7 Muaro Jambi
}

\author{
Bunga Ayu Wulandari, Indri Anastasia, Ahmad Ridha, Radiatan Mardiah, Adrefiza \\ FKIP, Universitas Jambi, Indonesia
}

\begin{abstract}
ABSTRAK
Kegiatan pengabdian masyarakat ini memberikan penyuluhan sosialisasi cerdas dan bijak menggunakan media sosial di era digital kepada siswa kelas IX SMPN 7 Muaro Jambi. Kegiatan ini dilatarbelakangi oleh fenomena penting yang muncul dalam kehidupan masyarakat sejak tahun 2000an, yaitu adanya jejaring media sosial seperti Friendster, YouTube, Facebook, Instagram, Twitter, Whatsapp, dan banyak lagi lainnya. Tidak dipungkiri adanya jejaring tersebut telah memberikan berbagai fasilitas kemudahan kepada penggunanya, misalnya dalam berkomunikasi, menyebarkan dan mendapatkan akses informasi. Seiring dengan banyaknya manfaat positif yang didapat, dampak negatif dari maraknya media sosial pun dirasakan nyata. Didasari oleh fenomena ini, maka tim pengabdian ini memberikan penyuluhan sosialisasi bagaimana menggunakan media sosial secara cerdas dan bijak sehingga tidak terpapar oleh pengaruh negatifnya. Sehingga diharapkan kedepannya, siswa-siswa ini akan menjadi individu-individu yang bertanggung jawab dalam menggunakan media sosial.
\end{abstract}

\section{PENDAHULUAN}

Bermula di tahun 1800an, manusia mulai mencari bentuk komunikasi saat individu-individu terpisah jarak. Pada masa itu ditemukan dua alat komunikasi penting yaitu telepon dan radio. Ketika komputer pertama dibuat pada tahun 1940, para peneliti dan insinyur mulai merancang jaringan untuk menghubungkan komputer-komputer dan menjadi cikal bakal kelahiran Internet. Dan sejak 1980, komputer-komputer rumahan bukan lagi sesuatu yang asing bukan hanya digunakan untuk kegiatan perkantoran. Sejalan dengan maraknya komputer dan majunya teknologi Internet maka media sosial pun lahir dan berkembang pesat. Ditahun 1997, diciptakanlah media sosial yang pertama yaitu Six Degrees. Penggunanya dapat mengunggah profil mereka dan berteman dengan pengguna lainnya. Dan ditahun 1999, blog pertama meraih kepopuleran, menciptakan sensasi media sosial yang masih dirasakan sampai saat ini. Di tahun 2000an bermunculan situs seperti MySpace, LinkedIn, YouTube, Facebook, Twitter, Whatsapp, Instagram, TikTok dan masih banyak lagi lainnya.

Di Indonesia, data dari Hootsuite di tahun 2019, pengguna media sosial di Indonesia berjumlah sekitar 150 juta orang, yang berarti 56 persen dari total populasi. Bukan hanya jumlahnya besar, tetapi juga pengguna aktif. Setiap hari rata-rata orang Indonesia menghabiskan waktu selamat 3 jam 26 menit untuk bermedia sosial. Sepuluh peringkat media sosial yang paling sering digunakan oleh orang-orang Indonesia, (Hootsuite, 2019), berturutturut adalah YouTube (88\%), Whatsapp (83\%), Facebook (81\%), Instagram (80\%), Line (59\%), Twitter (52\%), Facebook Messanger (47\%), Blackberry Messanger (38\%), LinkedIn (33\%), Pinterest (29\%), dan Skype (28\%). Sedangkan profil pengguna media sosial berdasarkan usia menurut survey Hootsuite (2019) seperti gambar dibawah: 


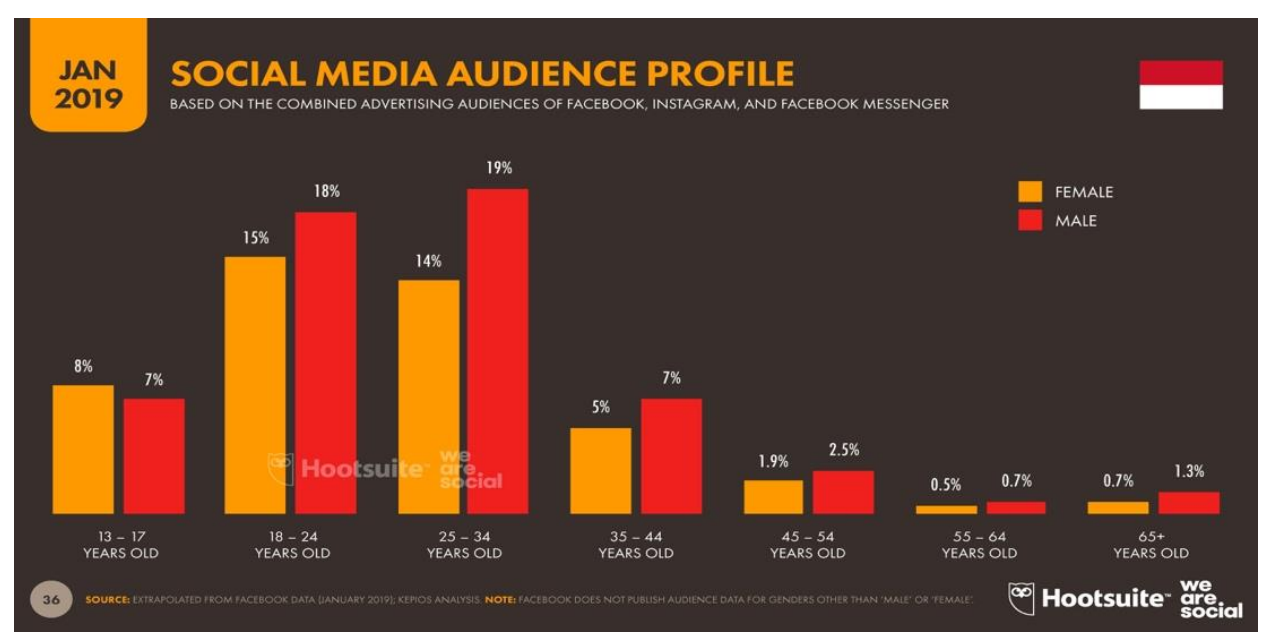

Sumber: Hootsite (2019)

Angka-angka tersebut berarti bahwa usia 18-24 tahun dan 25-34 tahun adalah pengguna terbanyak media sosial. Usia yang kerap disebut sebagai usia kaum milenial. Jika kenyataannya bahwa pengguna media sosial di Indonesia kebanyakan adalah remaja maka perlu dicermati bagaimanakah dan untuk apakah remaja tersebut menggunakan media sosial tersebut. Sherlyanita dan Rakhmawati (2016) menyebutkan dalam penelitian mereka bahwa dalam mesin pencarian Google, jika dimasukkan kata kunci "media sosial remaja" maka yang paling dominan muncul adalah berita negatif tentang dampak media sosial pada remaja. Contoh-contoh beritanya umumnya menyangkut pada cyberbullying, ujaran kebencian, dan pornografi.

Rifauddin (2016) dalam tulisannya mengupas secara khusus tentang cyberbullying yang dilakukan remaja melalui facebook. Cyberbullying didefiniskan sebagai bentuk intimidasi, misalnya melalui pesan kejam dan gambar yang tidak pantas yang dilakukan seseorang untuk melecehkan korban melalui perangkat teknogi (Rifauddin, 2016). Ia mengatakan bahwa perkembangan teknologi dikhawatirkan berdampak negatif pada remaja karena mereka dalam periode ini masih dalam masa transisi sehingga kejiwaan mereka masih mudah dipengaruhi rangsangan luar. Akibatnya, remaja masih rentan dengan kekerasan baik di dunia nyata ataupun maya (Rifauddin, 2016). Sedangkan menurut Komisioner Komisi Perlindungan Anak Indonesia (KPAI) Bidang Pendidikan, Retno Listyarti (dikutip dari Liputan6.com, 26 April 2019), cyberbully berupa kekerasan verbal dan psikis di dunia maya melalui media sosial adalah bully yang banyak terjadi dan terus mengalami peningkatan dari tahun ke tahun. Ia mengatakan sebelum tahun 2016, KPAI tidak pernah menerima kasus cyberbully, namun sejak tahun 2016 kasus ini terus mengalami kenaikan. Hasil riset Polling Indonesia bersama Asosiasi Penyelenggara Jasa Internet Indonesia (APJII) menunjukkan dari survey periode Maret sampai April 2019, 49 persen netizen atau warganet pernah menjadi korban bullying di media sosial (Tekno Kompas, 16 Mei 2019). Jika menilik di mesin pencarian Google, maka begitu banyak ditemukan kasus cyberbullying yang dilakukan remaja. Dampak dari cyberbullying ini baik bagi pelaku maupun korban sama negatifnya (Rifauddin, 2106). Menurutnya, pelaku akan merasa bersalah terus menerus, dan korban merasa sakit hati dan kecewa. Sedangkan korbannya akan mengalami depresi, kecemasan, ketidaknyamana, menurunnya prestasi disekolah, tidak mau bergaul dengan teman sebaya, menghindar dari lingkungan sosial bahkan bisa mengakibatkan upaya bunuh diri.

Ancaman ujaran kebencian pun menjadi perhatian dalam menggunakan media sosial. Ujaran kebencian atau 'hate speech" dalam kamus Merriam-Webster (2019) didefinisikan "ujaran yang ditujukan untuk menghina, menyinggung, atau mengintimidasi seseorang karena kepribadiannya (misalnya ras, agama, orientasi seksual, negara asal, atau ketidakmampuan). 
Gagliardone dkk (2015) menyebutkan bahwa ujaran kebencian 'hate speech" melalui media sosial berkembang sangat pesat dan mengkhawatirkan. Pradipta (2016) dalam risetnya menemukan bahwa dari 130 narasumber nya sebagian besar pernah melakukan ujaran kebencian, dalam bentuk kalimah menuduh atau menghakimi setidaknya dilakukan dua kali dalam sehari. Akibat dari ujaran kebencian ini yang memicu saling ejek di media sosial, seperti dicontohkan oleh Astuti (2019), misalnya bahkan dapat berujung tawuran antar pelajar SMK Sasmita dengan SMK Bhipuri di bulan Juli 2019 di Tangerang Selatan yang berujung maut.

Media sosial juga menjadi media bagi predator untuk melakukan kejahatan. Anak-anak dan remaja umumnya belum bisa mengidentifikasi sepenuhnya identitas orang yang dikenalnya di media sosial. Mereka rentan pula terpapar pornografi melalui media sosial yang bisa dengan mudah di akses melalui kiriman dari teman di media sosial. Dampaknya berakibat siswa kesulitan berkonsentrasi dalam belajar sehingga hasil belajarnya mengecewakan, melakukan hal yang terlarang, dan berperilaku yang berbeda dari biasanya (Haryani R, Mudjiran, \& Syukur, 2012) .

Bagi orangtua atau guru tentu sebisa mungkin mengawasi anak-anak dan remaja dalam menggunakan internet, khususnya media sosial. Akan tetapi, tentu tidak mungkin setiap detiknya bisa mengawasi anak-anak dan remaja menjelajahi dunia maya. Ketika mereka berada diluar pengawasan orang tua dan guru, yang paling ideal adalah anak-anak dan remaja mengetahui batasan dalam menggunakan internet dan media sosial. Oleh karenanya, mereka harus dibekali pengetahuan dan kesadaran tanggung jawab untuk cerdas dalam menggunakan media sosial. Karena itulah kegiatan pengabdian ini mengadakan sosialisasi kepada siswasiswa kelas IX SMP N 7 Muaro Jambi untuk belajar cerdas dan bijak dalam menggunakan media sosial.

\section{Permasalahan Mitra}

Mitra pengabdian ini adalah SMPN 7 Muaro Jambi. Subjek pengabdian adalah siswa-siswa kelas IX SMPN 7 Muaro Jambi, khususnya dengan 30 siswa-siswa. Diskusi yang dilakukan tim pengabdian ini dengan wakil kepala sekolah bidang kesiswaan SMPN 7 Muaro Jambi mendapatkan informasi bahwa hampir semua murid khususnya di kelas IX SMP N 7 Muaro Jambi menggunakan smartphone dan memiliki akun di media sosial yang secara aktif menggunakannya. Peraturan di sekolah adalah siswa tidak diperkenankan membawa smartphone nya ke sekolah. Akan tetapi diluar sekolah seringkali penggunaan smartphone dan media sosial melebihi batas-batas maksimum. Akibatnya siswa-siswa sering tidak mengerjakan tugas sekolah atau belajar secara mandiri. Harusnya smartphone menjadi sarana untuk belajar, malahan waktu siswa-siswa lebih banyak digunakan untuk ber media sosial seperti Facebook, Instagram, dan Whatsapp. Dan yang paling utama adalah baru-baru ini telah terjadi kasus penyebaran konten video porno melalui whatsapp diantara anak-anak kelas VII. Kasus yang terakhir ini membuat guru-guru sangat mendukung kegiatan pengabdian masyarakat yang tim pengabdian ini akan lakukan. Harapannya adalah siswa-siswa bisa memahami dampak positif dan negatif menggunakan media sosial. Manfaat yang bisa diambil dari penggunaan media sosial adalah mendapatkan informasi terkini tentang kemajuan pendidikan dan teknologi. Akan tetapi sedikit tidak dipungkiri dampak negatif yang bisa dirasakan oleh remaja misalnya bullying, ujaran kebencian, dan pornografi melalui media sosial. Hal-hal ini tidak dapat dihindari selama siswa-siswa menggunakan media sosial. Diharapkan setelah kegiatan pengabdian ini, tidak terjadi lagi penyalahgunaan media sosial untuk menjadi sarana penyebaran pornografi ataupun bullying. Sehingga kedepannya siswasiswa akan cerdas dan bijak dalam menggunakan sosial media. Terlebih sasaran dari sosialisasi tim pengabdian kali ini adalah siswa-siswa kelas IX yang biasanya mulai berani dalam menyuarakan pendapat dan mencoba-coba segala sesuatu. Dengan pertimbangan ini maka tim pengabdian memberikan gambaran dan pengetahuan kepada anak-anak usia ini sehingga 
kedepannya jika mereka memiliki kesadaran dan tanggung jawab dalam menggunakan media sosial juga akan menularkannya kepada teman sebaya dan adik-adik kelasnya.

\section{METODE PELAKSANAAN}

Metode pelaksanaan dalam pengabdian masyarakat dilakukan dalam bentuk kegiatan sosialisasi sehari kepada siswa-siswa kelas IX SMP N 7 Muaro Jambi. Materi sosialisasi diberikan dalam bentuk penyuluhan interaktif dengan siswa tentang:

1. Penjelasan umum tentang fenomena internet dan media sosial saat ini.

2. Penjelasan tentang dampak positif dan negatif penggunaan media sosial.

3. Penjelasan tentang cara menggunakan media sosial secara cerdas dan bijak.

Dikarenakan situasi pandemic Covid-19 maka kegiatan pengabdian dilakukan secara daring melalui zoom meeting pada tanggal 27 Juli jam 16.00. Pemilihan sore hari untuk waktu kegiatan pengabdian dengan pertimbangan tidak mengganggu waktu belajar daring siswasiswa dengan guru mereka disekolah. Sebelum diadakan penyuluhan siswa-siswa diminta untuk mengisi survey tentang penggunaan media sosial melalui Google Forms.

Penyuluhan berlangsung selama satu jam. Setelah selesai penyuluhan, diadakan sesi diskusi tanya jawab dengan peserta siswa-siswa untuk berdiskusi tentang pengalaman atau masalah yang mereka hadapi dalam menggunakan media sosial. Dalam acara diskusi ini siswasiswa saling berbagi pengalaman sekaligus bersama-sama mencari pemecahan masalah. Demikianlah Alhamdulillah kegiatan pengabdian telah selesai dilaksanakan. Foto-foto kegiatan penyuluhan dapat dilihat pada gambar dibawah berikut:

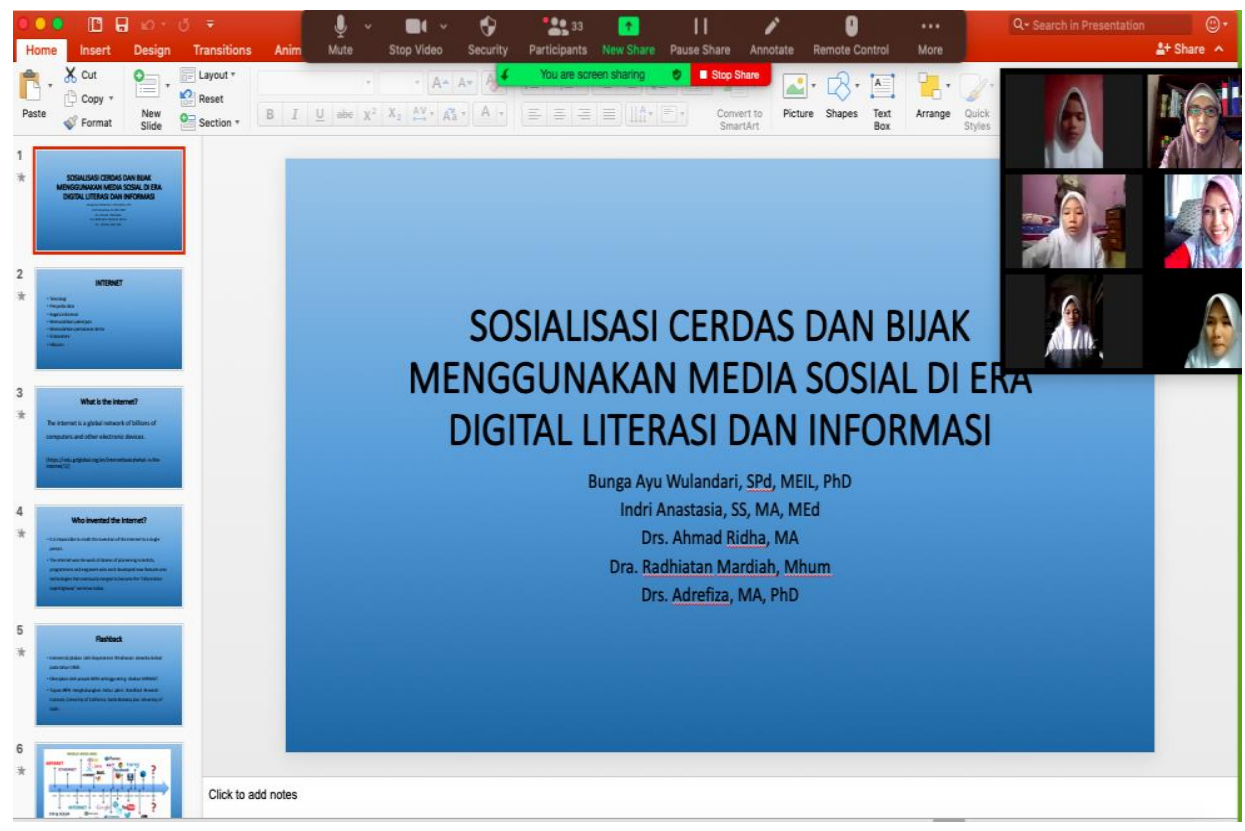



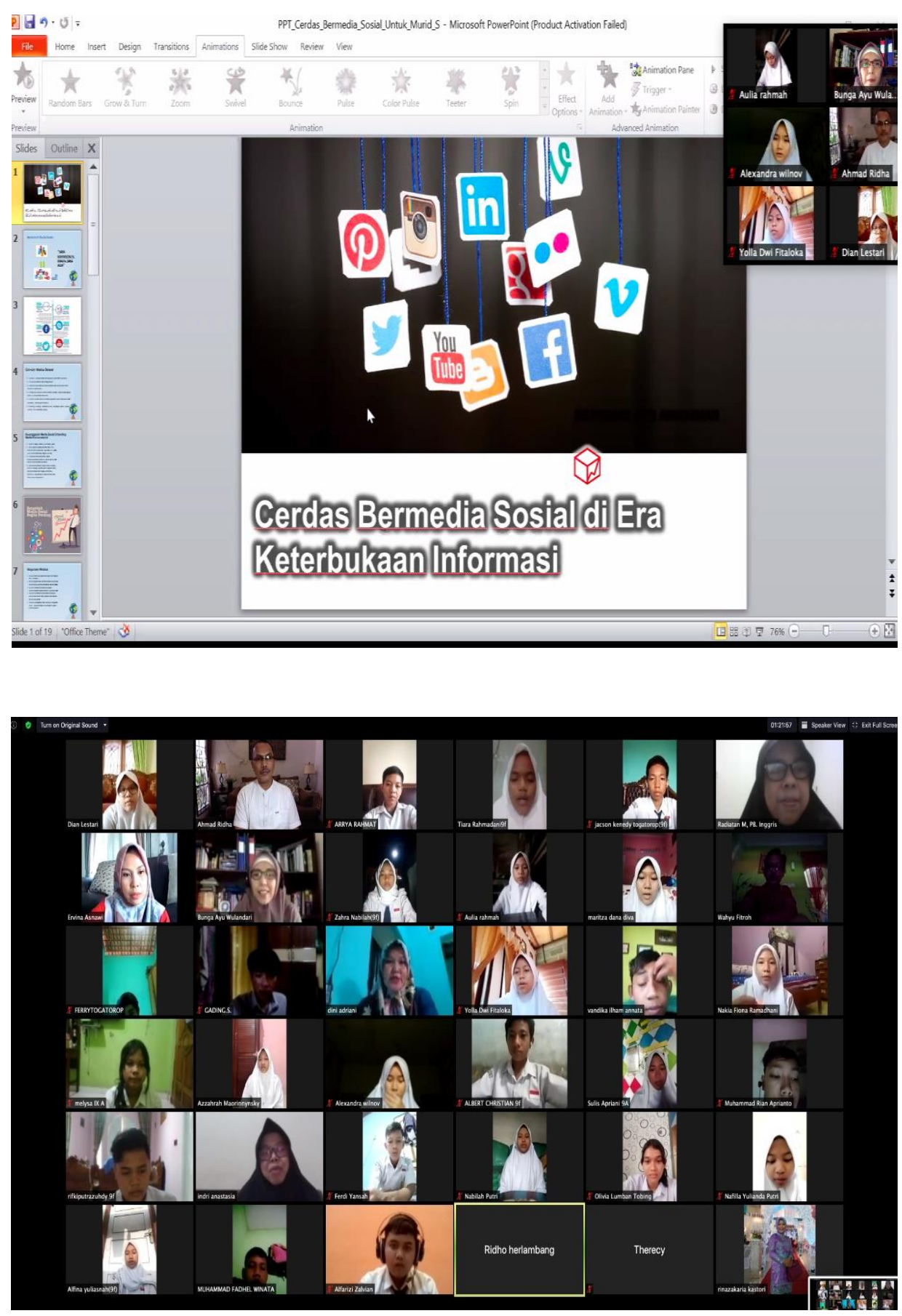

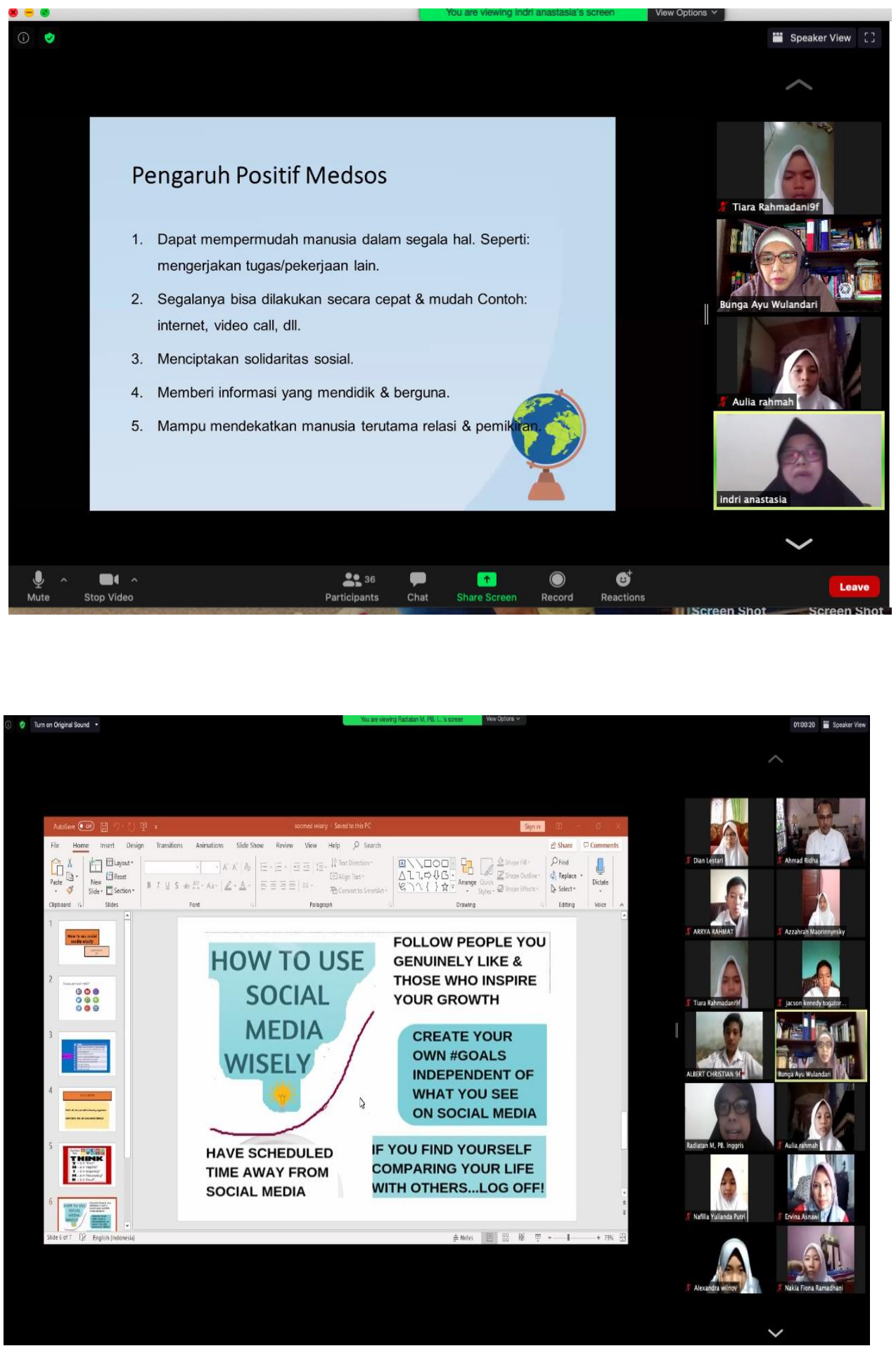

\section{Hasil yang dicapai}

Hasil yang telah dicapai dalam kegiatan pengabdian dengan judul 'Sosialisasi Cerdas dan Bijak Menggunakan Media Sosial di Era Digital Literasi dan Informasi kepada Siswa Kelas IX SMP N 7 Muaro Jambi' ini adalah telah dilakukannya kegiatan pengabdian dalam bentuk penyuluhan sehari kepada siswa-siswa kelas IX SMPN 7 Muaro Jambi melalui Zoom meeting. Peneliti juga telah melakukan penyebaran questionnaires melalui Google Form sebelum dilakukan penyuluhan yang berisi pertanyaan-pertanyaan tentang penggunaan media sosial. Banyak temuan menarik yang didapat dari pengambilan data questionnaires dan pertanyaan 
terbuka, antara lain bahwa 30 siswa-siswa yang menjadi peserta penyuluhan ini memiliki ponsel sendiri, dan mereka pernah mengalami perundungan serta di kirimi video atau link yang isinya tidak pantas. Data dari survey adalah sebagai berikut:

Apakah kamu memiliki ponsel sendiri?

28 responses

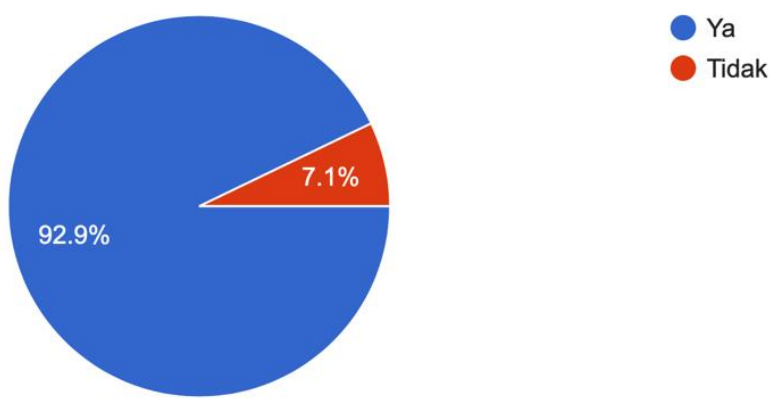

Kamu menggunakan media sosial apa?

29 responses

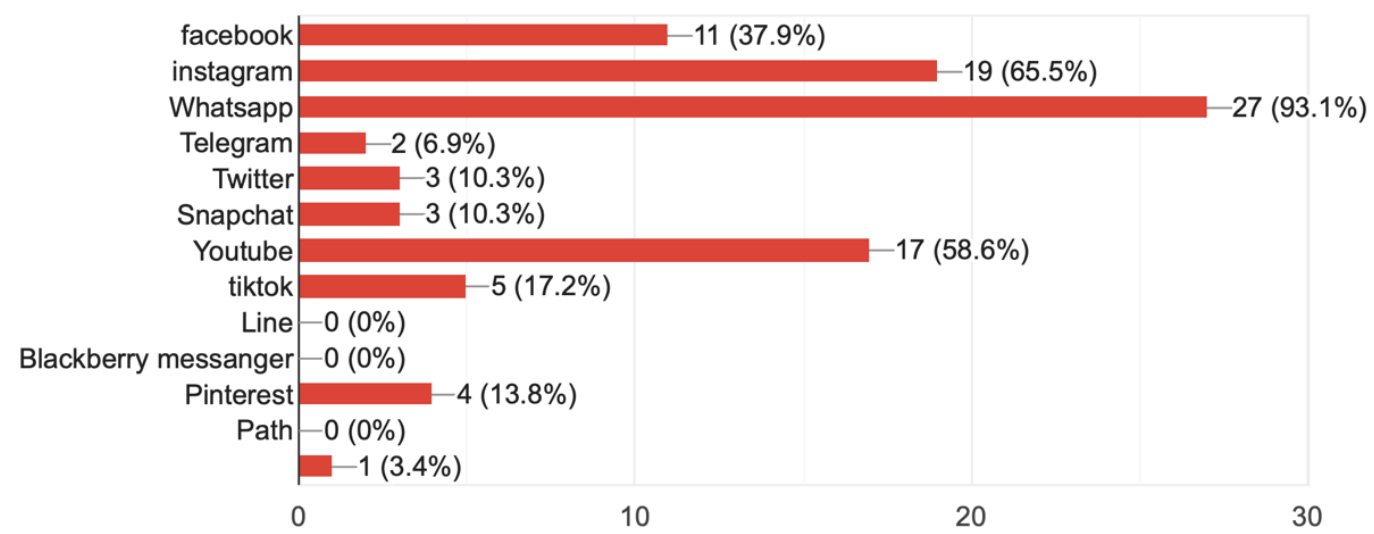

Kamu menggunakan media sosial untuk apa?

29 responses

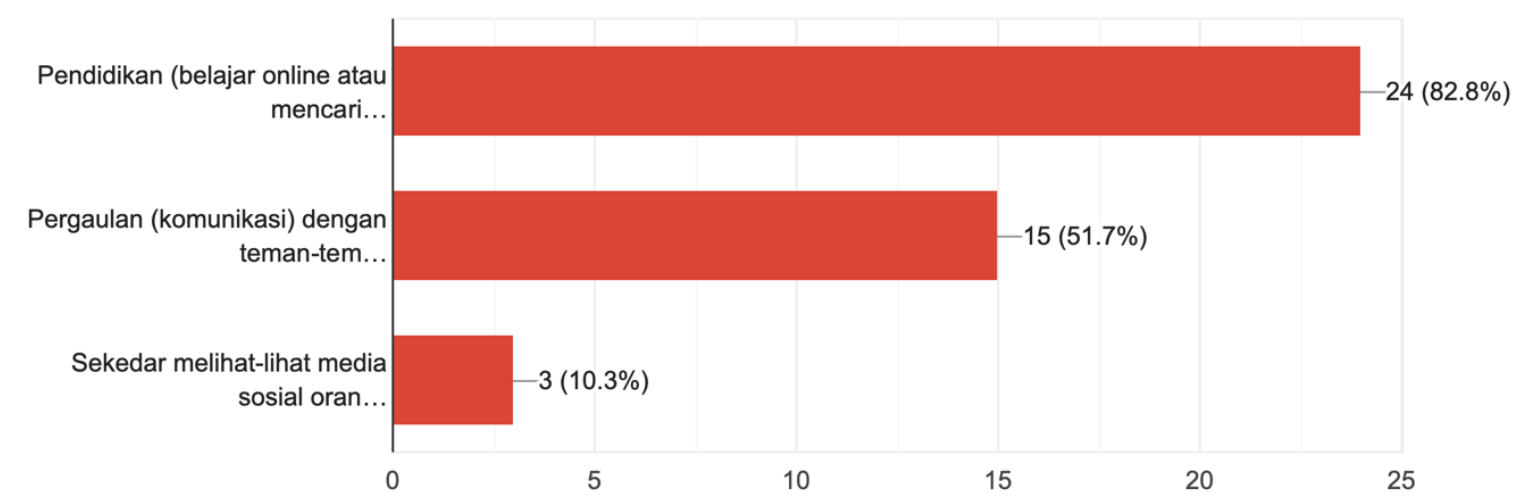


Pernahkah kamu mengalami bully (misalnya diejek atau direndahkan) di media sosial?

29 responses

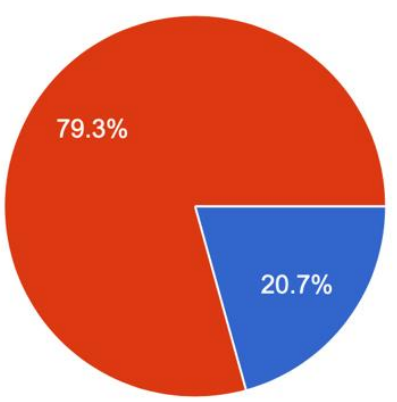

Kalau kamu pernah membully teman atau orang lain, biasanya hal apa yang kamu bully? 12 responses

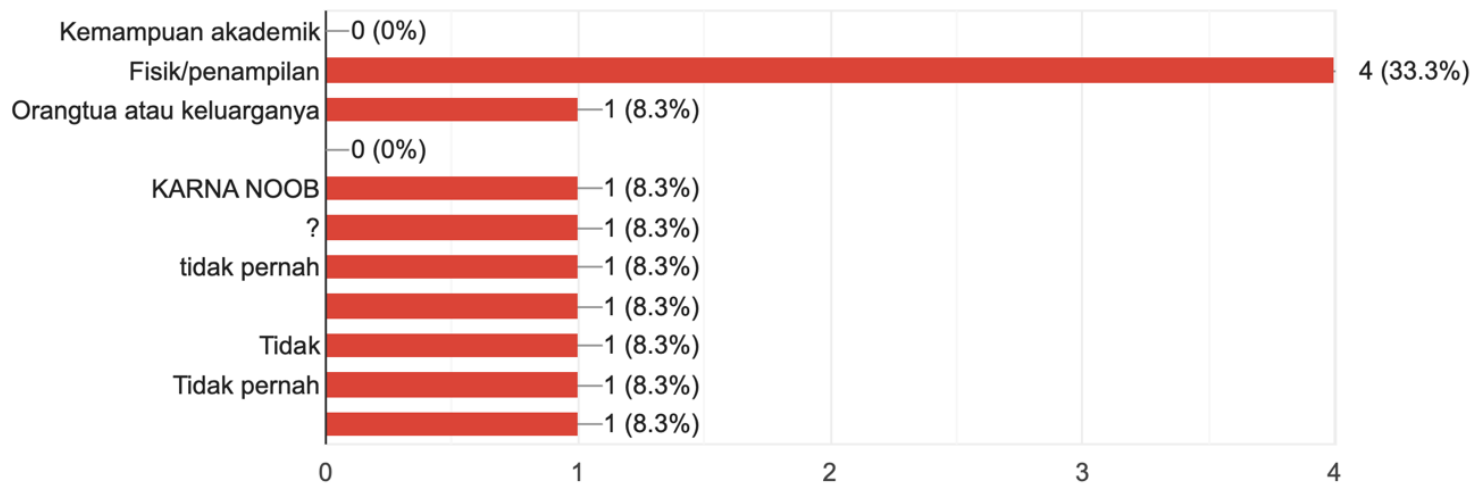

\section{KESIMPULAN}

Kesimpulan yang didapat dari hasil survey yang dilakukan sebelum kegiatan pengabdian diketahui siswa-siswa mengakui bahwa mereka mengalami bully. Kemudian dalam sesi tanya jawab siswa-siswa sangat tertarik untuk mendengarkan dampak positif dan negative dari penggunaan media sosial karena faktor usia yang masih sangat muda mereka belum memikirkan sejauh mana media sosial dapat memberikan dampak yang tidak baik pula.

\section{Saran}

Saran yang bisa tim pengabdian sampaikan adalah perlunya penyuluhan reguler tentang penggunaan media sosial kepada siswa-siswa sekolah menengah. Dikarenakan terbuka segala informasi seringkali orangtua tidak bisa terus menerus menyaring apa yang dilihat anak-anak melalui media sosial sehingga jika anak-anak memiliki kemampuan filter sendiri mereka akan bisa menjaga diri dari dampak negatif media sosial. 


\section{DAFTAR PUSTAKA}

Asosiasi Penyelenggara Jasa Internet Indonesia (APJII), (16 Mei 2019). 49 persen netizen di Indonesia pernah mengalami "bullying" di medsos. Diambil dari https://tekno.kompas.com/read/2019/05/16/08290047/49-persen-netizen-di-indonesiapernah-mengalami-bullying-di-medsos.

Astuti, F. (2019). Perilaku hate speech pada remaja di media sosial instagram (Skripsi mahasiswa S1). Universitas Muhammadiyah, Surakarta.

Gagliardone, I., Gal, D., Alves, T., \& Martinez, G. (2015). Countering Online Hate Speech. Unesco Publishing.

Haryani M. R., Mudjiran, \& Syukur, Y. (2012). Dampak pornografi terhadap perilaku siswa dan upaya guru pembimbing untuk mengatasinya. Konselor, 1(1), 1-8.

Hate speech. (n.d.). In Merriam-Webster dictionary. Diambil dari https://www.merriamwebster.com/dictionary/hate\%20speech

Listyarti, R. (26 April 2019). Cerita akhir pekan: Kasus cyber bully terus meningkat di media sosial. Liputin6.com. Diambil dari https://www.liputan6.com/lifestyle/read/3951545/cerita-akhir-pekan-kasus-cyber-bullyterus-meningkat-di-media-sosial

Pradipta, A. (2016). Fenomena Perilaku Haters di Media Sosial (Skripsi mahasiswa S1). Universitas Diponegoro, Semarang.

Rifauddin, M. (2016) Fenomena cyberbullying pada remaja. Jurnal Ilmu Perpustakaan, Informasi, dan Kearsipan Khizanah Al-Hikmah, 4(1), 35-44.

Sherlyanita, A. K., \& Rakhmawati, N. A. (2016). Pengaruh dan pola aktivitas penggunaan internet serta media sosial pada siswa SMPN 52 Surabaya. Journal of Information Systems Engineering and Business Intelligence, 27(1), 17-22. 